\title{
Membangun Tv Dakwah Berbasis Streaming Technology
}

\author{
Oleh : Muhayat
}

\begin{abstract}
$D a^{\prime} w a h$ is an activity that is universal, not limitation of space and time, it all depends on the needs and circumstances the object of Da'wah. In the perspective of contemporary, Da'wah through the mass media, especially television is still very relevant because television as an audio-visual medium, is able to capture 94\% channel entry message-either message or information come to our brain through both eyes and ears. Once displayed agenda in television, normal people could remember $50 \%$ from what they see and hear. In other words, people will remember $85 \%$ from what they see and hear from television after 3 hours and 65\% for the next 3 days. But to build a conventional TV are very expensive, it is necessary creativity to realize Da'wah TV reliable yet inexpensive. To achieve this, the most powerful candidate is build Da'wah TV based on streaming technology, a technology that allows broadcast TV in real-time as well as On Demand through the Internet. This paper will describe the analysis and design Da'wa TV based on streaming technology with systems development methodology Luther Version consisting of six phases; concept, design, material collecting, assembly, testing and distribution.
\end{abstract}

Keyword : Da'wah TV, Streaming, Technology

\section{A. Pendahuluan}

Dakwah Islam merupakan aktivitas yang bersifat universal, tidak mengenal batasan ruang dan waktu, semuanya tergantung dari kebutuhan dan keadaan objek dakwah. Dalam persfektif kekinian dakwah Islam melalui media massa, khususnya televisi masih sangat relevan dan menjadi sebuah keniscayaan bagi segenap pegiat dakwah, mengingat pengaruh televisi yang oleh hasil penelitian Dwyer (1988) mampu merebut 94\% saluran masuknya pesan-pesan atau informasi ke dalam jiwa manusia yaitu lewat mata dan telinga, TV mampu untuk membuat orang pada umumnya mengingat $50 \%$ dari apa yang mereka lihat dan dengar di layar TV walaupun hanya sekali ditayangkan, atau secara umum orang akan ingat $85 \%$ dari apa yang mereka lihat di TV setelah tiga jam kemudian dan $65 \%$ setelah tiga hari kemudian (Al-Khudri, 2005).

Televisi sebagai media dakwah dapat dipahami sebagai sarana yang efektif dan efisien dalam menyebarkan risalah agama sehingga mampu mempengaruhi perilaku masyarakat ke arah yang lebih baik. Hal ini sangat relevan dengan filosofi dakwah yang mengandung ide tentang progresivitas, sebuah proses terus menerus kepada yang baik dan yang lebih baik dalam mewujudkan tujuan dakwah. Dengan begitu, dalam dakwah terdapat suatu ide dinamis, sesuatu yang terus tumbuh dan berkembang sesuai dengan tuntunan ruang dan waktu (Ilaihi, 2010).

Seiring dengan perkembangan zaman, televisi tidak lagi hanya sebatas TV broadcast yang menggunakan teknologi radio di gelombang khusus seperti saat ini, penyiaran TV telah menyebar ke sarana yang lain termasuk internet. Banyak teknologi yang bisa digunakan di internet, tetapi kandidat yang paling kuat adalah streaming technology, sebuah teknologi yang memungkinkan penyiaran TV secara real time (siaran langsung) maupun secara On Demand (atas permintaan pemirsa) melalui jaringan internet.

Atas dasar inilah penulis akan membangun (analisis dan desain) TV Dakwah berbasis Streaming Technology, dengan pertimbangan bahwa, pertama; Dakwah kekinian harus berkembang sesuai dengan tuntutan zaman, kedua; televisi merupakan media dakwah yang sangat efektif dan efisien dalam penyampaian risalah dakwah, ketiga; Membangun TV Dakwah berbasis Streaming Technology relatif tidak membutuhkan biaya yang besar dibanding membangun TV konvensional yang memerlukan biaya hingga ratusan juta rupiah. Dalam tulisan ini penulis membatasi 
laporan Membangun TV Dakwah berbasis Streaming Technology hanya sampai pada fase analisis dan desain, dan untuk implementasi hingga pengujian sistem akan dilakukan penelitian lanjutan.

\section{B. Landasan Teori}

\section{Televisi Dakwah}

Terminologi Televisi Dakwah dapat ditelusuri dari akar kata televisi dan dakwah itu sendiri. Televisi terdiri dari kata "tele" yang berarti jauh dan "visi" (vision) yang berarti pengelihatan dengan asumsi televisi jauhnya ditranmisikan dengan pengelihatannya diwujudkan dengan prinsip-prinsip kamera sehingga menjadi gambar, baik dalam bentuk gambar hidup atau bergerak maupun gambar diam (still picture) (Fatmawati, 2009).

Televisi merupakan perkembangan medium berikutnya setelah radio, yang ditemukan dengan karakternya yang spesifik yaitu audio-visual. Peletak dasar utama teknologi pertelevisian tersebut adalah Paul Nipkaw dari Jerman tahun 1884. Ia menemukan sebuah alat yang kemudian disebut sebagai jantra nipkaw atau nipkaw sheibe, penemuannya tersebut melahirkan electriche teleskop atau televisi elektrik (Muda, 2005:4). Televisi merupakan media audio-visual yaitu informasi disampaikan dengan menampilkan unsur gambar dan suara secara bersamaan (Amin, 2009).

Televisi merupakan paduan audio dari segi penyiaran (broadcast) dan video dari segi gambar bergeraknya (moving images). Para pemirsa menangkap siaran televisi karena ada prinsip-prinsip radio yang mentransmisikan dan melihat gambar- gambar yang bergerak dan hidup karena unsur-unsur film yang memvisualisasikannya (Fatmawati, 2009). Televisi merupakan media dari jaringan komunikasi yang berlangsung satu arah, komunikatornya melembaga, pesannya bersifat umum, sasarannya menimbulkan keserempakan, dan komunikannya bersifat heterogen (Fatmawati, 2009).
Televisi memiliki karakter yang khas, wajahnya sebagai media hiburan dan jurnalisme mudah bercampur aduk. Secara institusional, stasiun televisi dapat dibedakan dari karakter utamanya, yaitu intensi fungsional yang diembannya. Dikenal dua tipe orientasi penyiaran, yaitu televisi publik (public TV) dan televisi komersial (commercial TV).

Sedangkan kata "dakwah" berarti panggilan, seruan atau ajakan. Bentuk perkataan tersebut dalam bahasa Arab disebut "masbdar". Sedangkan dalam bentuk kata kerjanya berarti memanggil, merayu atau mengajak (da'a, yad'u, da'watan) (Saputra, 2011). Pengertian dakwah menurut istilah sebagai berikut:

a. Dakwah Islam sebagai upaya mengajak umat dengan cara bijaksana kepada jalan yang benar sesuai dengan perintah Tuhan untuk kemaslahatan di dunia dan akhirat (Saputra, 2011).

b. Dakwah Islamiyyah yaitu mengajak orang lain untuk meyakini dan mengamalkan aqidah dan syariah yang terlebih dahulu telah diyakini dan diamalkan oleh pendakwah itu sendiri (Amin, 2009).

c. Dakwah Islam pada hakikatnya merupakan aktualisasi imani yang dimanifestasikan dalam suatu sistem kegiatan manusia beriman dalam bidang kemasyarakatan yang dilaksanakan secara teratur untuk mempengaruhi cara merasa, berfikir, bersikap, dan bertindak manusia pada tataran kenyataan individual dan sosiokultural dalam rangka terwujudnya ajaran Islam dalam semua segi kehidupan dengan menggunakan cara tertentu (Amin, 2009).

Dari beberapa pengertian televisi dan dakwah tersebut di atas, menurut penulis pada prinsipnya televisi dakwah merupakan media penyiaran audio-visual yang mengambil peran sebagai medium sumber informasi, pendidikan, dakwah dan kontrol sosial, yang diharapkan mampu menjadi inspirasi, referensi dan motivasi bagi khalayak umat, guna meningkatkan harkat, martabat dan kualitas kehidupan. Sebagai 
medium dakwah dalam konteks luas, TV Dakwah akan mengambil peran aktif bagi upaya perbaikan kualitas kehidupan bangsa dan manusia secara universal, melalaui isi siaran yang bermutu, mencerdaskan, mencerahkan, membentuk watak yang berbudi pekerti luhur.

Media televisi di Indonesia terus berkembang baik secara kualitatif maupun kuantitatif. Keadaan ini dapat memberi kontribusi positif bagi masyarakat terutama bagi masyarakat yang tinggal di wilayah yang terpencil. Tayangan televisi yang bermuatan pendidikan dan dakwah dapat dijadikan alternative mendapatkan pendidikan sekaligus siraman rohani (Rahmi, 2012).

Siaran televisi bukanlah sekedar tontonan, tetapi juga merupakan suatu kenyatan yang sering diuji secara idiologis dan normatif. Oleh karena itu pengelola televisi tidak hanya memberi tontonan tetapi juga harus memperhitungkan idiologi dan norma yang dianut sebagian besar orang dalam masyarakat (Fatmawati, 2009).

Televisi pada pokoknya memiliki tiga fungsi yaitu, pertama fungsi penerangan (the information function) televisi dalam memuat fungsi penerangan harus mencakup dua faktor yaitu faktor immediacy yaitu langsung dan dekat, faktor yang kedua realism yaitu kenyataan. Kedua, fungsi pendidikan (the education function) sesuai dengan makna pendidikan yakni meningkatkan pengetahuan dan penalaran masyarakat. Televisi merupakan sarana yang ampuh untuk menyiarkan pendidikan kepada khalayak. Ketiga, fungsi hiburan (the entertainment function) sebagian besar alokasi waktu masa siaran di isi oleh acara-acara hiburan, melalui gambar hidup beserta suaranya bagaikan kenyataan dan dapat dinikmati oleh khalayak (Fatmawati, 2009).

Tiga fungsi televisi di atas harus dicermati dan dimanfaatkan oleh insan yang berkecimpung di pengembangan dakwah Islam, karena kecenderungan televisi menyita waktu, waktu yang terpakai untuk menonton televisi jauh lebih banyak dibandingkan dengan kegiatan penyerapan pengetahuan dan nilai-nilai lainnya. Keadaan ini harus dapat dimanfaatkan oleh praktisi dakwah untuk mengemas acara dakwah yang lebih menarik, solutif, dan komunikatif. Dakwah melaui televisi harus memuat pembaharuan dalam kemasannya, setidaknya menyangkut empat hal pokok yaitu, pembaharuan konsep dakwah, perluasan dan penguatan jaringan/kerjasama dengan lembaga-lembaga yang bergerak di bidang dakwah, penguatan dana primer dan skunder untuk mendanai program dakwah, dan peningkatan kualitas dan kuantitas da’i dan da'iah, khususnya yang sudah populer di media televisi (Fatmawati, 2009).

Pertama, pembaharuan konsep konsep di media televisi mengacu pada Al-qur'an dapat didefinisikan sebagai panggilan aktualisasi iman, pencerahan agama, dan proses masyarakat menuju kualitas "khairu ummah". Allah berfirman dalam surat AliImran ayat 110:

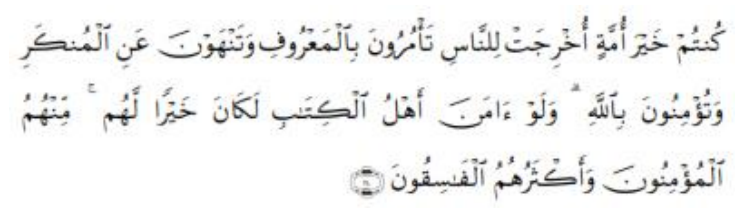

Artinya: "Kamu adalah umat yang terbaik yang dilabirkan untuk manusia, menyuru kepada yang ma'ruf, dan mencegah dari yang munkar, dan beriman kepada Allah. Sekiranya Abli Kitab beriman, tentulah itu lebih baik bagi mereka, di antara mereka ada yang beriman, dan kebanyakan mereka adalah orang-orang yang fasik" (Departemen Agama RI, 2005).

Upaya untuk menyeru kepada yang ma'ruf dan mencegah yang mungkar dan untuk mewujudkan pada Islam dan Iman dapat dilakukan dengan berbagai cara salah satunyanya dengan dakwah melaui media televisi. Dakwah melalui media televisi di era 
globalisasi ini harus merupakan ikhtiar yang bersungguh-sungguh untuk memberikan "hidangan", yang benar-benar enak, dan dibutuhkan umat dibungkus dalam kemasan yang menarik, sesuai kemajuan dan perkembangan masyarakat (Fatmawati, 2009).

Kedua, perluasan dan penguatan jaringan/kerjasamanya dengan lembaga-lembaga yang bergerak di bidang dakwah, dengan paradigma baru yang menekankan pembangunan dalam perluasan kerjasama dengan lembaga-lembaga dakwah. Dengan kerjasama ini diharapkan dakwah melalui media televisi dapat lebih bergairah karena didukung oleh berbagai pihak (Fatmawati, 2009).

Ketiga, penguatan dana primer dan skunder untuk menandai program dakwah karena ruh dari penayangan kemasan dakwah melalui televisi adalah wajib ada dana yang cukup besar. Hal ini mengacu pada idiologi industri media massa adalah profit yang tinggi. Untuk itu, dakwah haruslah dikemas dengan cara dan metode yang tepat dan pas. Dakwah harus tampil secara aktual, faktual, dan kontekstual. Dalam mengemas program dakwah ada beberapa yang perlu diperhatikan oleh Crew produksi yaitu:

a. Corak kemajemukan (pluralitas) masyarakat Indonesia sebagai suatu bangsa adalah kebhinekaan dalam beberapa aspek kehidupan meliputi pandangan hidup, sosio-kultural, agama, suku, bahasa, dan politik.

b. Tendensi perkembangan masyarakat yang banyak dipengaruhi oleh kemajuan teknologi serta modernitas yang telah mulai menjiwai trans-pembangunan nasional ke arah perubahan sosial. Nilai-nilai kultural dan agama cepat atau lambat harus dapat secara normatif kultural mengontrol serta menjiwainya.

c. Corak kehidupan psikologis masyarakat modern dan tradisional mengandung ciriciri yang berbeda satu sama lain (Fatmawati, 2009).
Kemasan dakwah melalui media televisi didominasi dengan model dialog, monolog, tabligh. Diperlukan kreatifitas untuk mengembangkan dakwah di televisi dengan mempertimbangkan ketentuan-ketentuan diatas.

Keempat, peningkatan kualitas dan kuantitas da'i dan da'iah baik secara moral, ahlak, intelektual, spiritual dan sosial. Insan akademik dan pertelevisian perlu melakukan pengembangan kemampuan sumber daya baik melalui pendidikan atau pelatihan agar menghasilkan da'i dan da'iah yang berkualitas, kreatif, komunikatif, marketable dalam program dakwah televisi (Fatmawati, 2009:179).

\section{Teknologi Streaming}

Streaming merupakan sebuah teknologi yang mampu mengkompresi atau menyusutkan ukuran file audio dan video agar mudah ditransfer melalui jaringan Internet. Pentransferan file audio dan video tersebut dilakukan secara stream atau terus-menerus. Dari sudut pandang prosesnya, streaming berarti sebuah teknologi pengiriman file dari server ke client melalui jaringan packet-based semisal Internet. File tersebut berupa serangkaian paket time-stamped yang disebut stream.

Sedangkan dari sudut pandang pengguna, streaming adalah teknologi yang memungkinkan suatu file dapat segera dijalankan tanpa harus menunggu selesai di-download seluruhnya dan terus "mengalir" tanpa ada interupsi. Sebelum teknologi streaming tersebut diperkenalkan secara luas, orang harus men-download secara utuh file audio atau video sebelum dapat didengar atau ditonton dikomputer. Untuk men-download file tersebut hingga selesai tentu saja memerlukan waktu yang cukup banyak. Sekedar contoh, jika sebuah file video besarnya adalah $10 \mathrm{Mb}$, maka diperlukan proses sekitar 15 menit apabila menggunakan akses Internet dengan kecepatan 56 KBps.

Ada dua jenis layanan yang dapat disuguhkan oleh Internet broadcasting ini, yaitu on-demand dan live/Real-Time. On-demand mengacu pada broadcasting yang menyiarkan 
file media yang telah direkam sebelumnya. Sedangkan Internet broadcasting live, atau biasa dikenal pula dengan istilah livecasting, menyiarkan suatu file media saat itu juga ketika suatu kejadian tengah berlangsung (real time). (Donny, 2002).

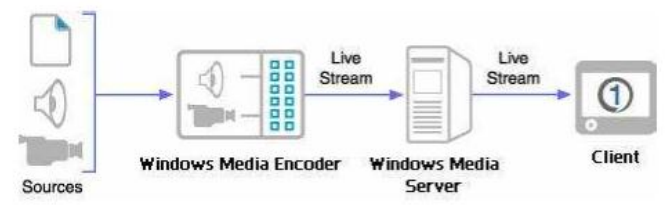

Gambar 1 : Proses Real-Time/Live Streaming

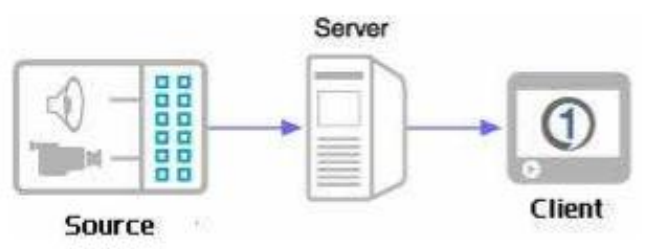

Gambar 2 : Proses On Demand Streaming

Secara teknis, Internet broadcasting yang menggunakan teknologi streaming ini terbagi atas dua jenis, yaitu unicasting dan multicasting. Broadcasting dalam keseharian adalah proses pengiriman data dari satu titik ke banyak titik. Proses broadcasting ini berlaku pada pemancaran siaran radio atau televisi melalui gelombang udara atau frekuensi tertentu yang sebenarnya semua frekuensi tersebut diterima oleh antena pesawat penerima. Client hanya memilih frekuensi mana yang akan didengarkan.

Unicasting adalah proses pengiriman data dari satu titik ke satu titik yang lainnya, dan non real time sebagaimana layaknya layanan dasar berbasis IP (internet protoco). Proses unicasting seperti mengirimkan e-mail yang isinya sama secara satu persatu ke client. Dengan unicasting, sebuah file media yang telah dibuat, akan disimpan terlebih dahulu di sebuah media penyimpanan. Jika ada pengguna Internet yang ingin menikmati file media tersebut, maka file tersebut akan di-streaming- kan terlebih dahulu oleh sebuah streaming server sebelum disajikan ke komputer pengguna tersebut. Proses penyampaian file media dari media penyimpanan hingga ke komputer pengguna tersebut terjadi berulangulang, tergantung berapa banyak orang yang ingin menikmati file tersebut. Untuk itulah maka unicasting cocok untuk Internet broadcasting yang non real time dan on-demand.

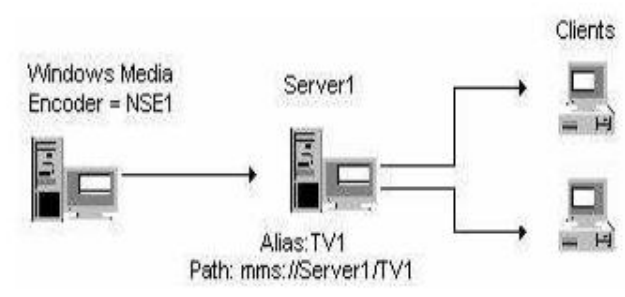

Gambar 3 : Unicast Streaming

Multicasting adalah proses pengiriman data dari satu titik ke banyak titik yang merupakan bagian dari satu grup tertentu dan yang memang menginginkan data tersebut, seperti apabila mengirimkan sebuah e-mail ke suatu mailing-list kelompok kerja yang terbatas. Multicasting ini real-time dan saling berbagi rute antar titik untuk menuju ke titik tujuan yang beragam tersebut. Dengan multicasting, file media yang tengah dibuat langsung dibawa ke streaming server untuk distreaming-kan dan hasilnya langsung disalurkan saat itu juga ke satu titik tertentu untuk disebarkan.

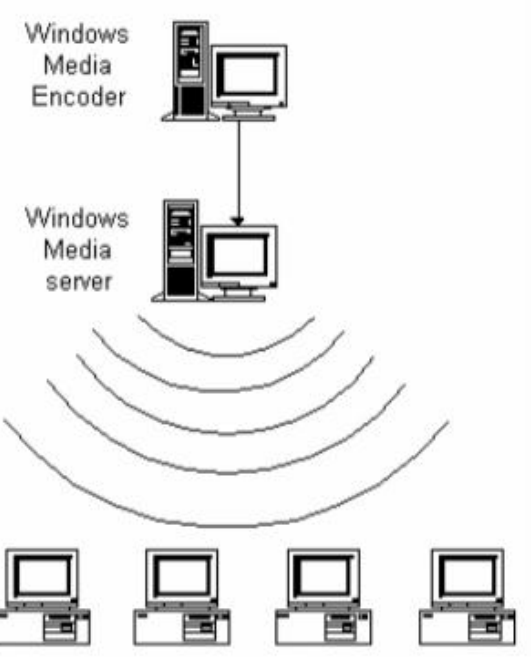




\section{Gambar 4 : Multicast Streaming}

Proses penyampaian file media dari proses pembuatan hingga ke komputer pengguna tersebut hanya terjadi sekali saja, yaitu saat file media tersebut dibuat untuk pertama kalinya. Untuk itulah maka multicast cocok untuk Internet broadcasting yang real-time dan livecasting. (Donny, 2002).

Streaming adalah sebuah teknologi untuk memainkan file video atau audio secara langsung ataupun dengan pre-recorded dari sebuah mesin server (webserver). Dengan kata lain, file video atau audio yang terletak pada sebuah server dapat secara langsung dijalankan pada komputer client sesaat setelah ada permintaan dari user sehingga proses download file video atau audio yang menghabiskan waktu cukup lama dapat dihindari.

Sebuah file video atau audio di stream maka akan terbentuk sebuah buffer di komputer client dan data video atau audio tersebut akan mulai didownload kedalam buffer yang telah terbentuk pada mesin client. Dalam waktu sepersekian detik, buffer telah terisi penuh dan secara otomatis file video atau audio akan dijalankan oleh sistem. Sistem akan membaca informasi dari buffer sambil tetap melakukan proses download file sehingga proses streaming tetap berlangsung ke mesin client. Delay waktu sesaat sebelum file video atau dijalankan berkisar 10-30 detik. (Azikin Askari \& Purwanto Yudha, ST, 2005).

Secara konsep, proses streaming dibagi kedalam tiga tahap, yaitu: 1). Mempartisi/ membagi data video/audio yang telah terkompresi kedalam paket paket data. 2). Pengiriman paket-paket data video/audio, 3). Penerima (receiver) mulai men-decode dan menjalankan video/audio walaupun paket data yang lain masih dalam proses pengiriman ke mesin PC (personal computer).

Beberapa keunggulan video streaming antara lain tidak membutuhkan media penyimpanan yang besar serta delay yang relatif lebih singkat, hanya sesaat sebelum menjalankan video di mesin PC client. (Azikin Askari \& Purwanto Yudha, ST , 2005).

Secara arsitektur, streaming tecbnology tersusun dari kombinasi server, Player, transmisi dan metode encoding yang digunakan. Berikut bagan komponen penyusun sistem streaming:

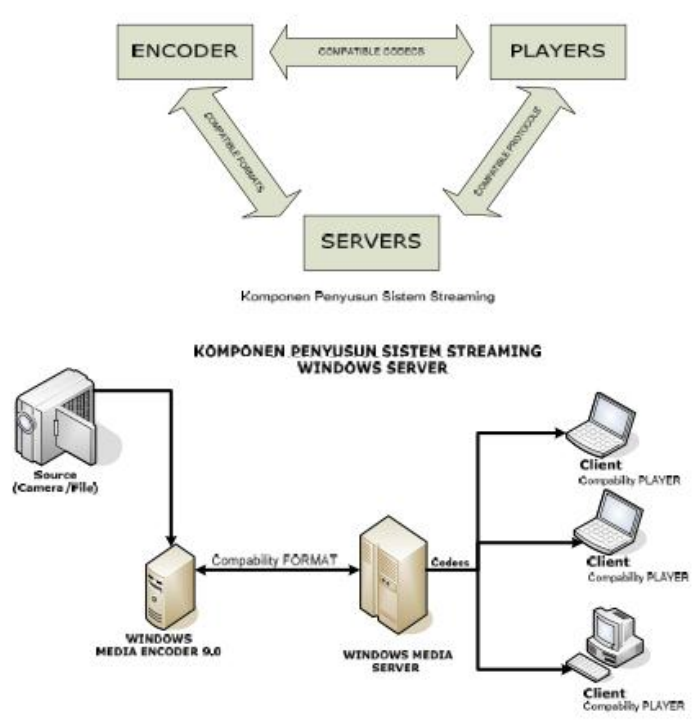

Gambar 5 : Streaming Technology Architecture

\section{Metodologi}

Membangun TV Dakwah berbasis streaming technology pada dasarnya dapat menggunakan motodologi pembangunan sistem multimedia, karena pada hakikatnya streaming technology merupakan gabungan dari dua atau lebih dari elemen-elemen multimedia yang terdiri atas: Teks, Grafik, Audio, Video dan Animasi (Prabhat. dkk., 1996).

Adapun metodologi pengembangan sistem multimedia, dalam membangun TV Dakwah berbasis streaming technology ini menggunakan metodologi pengembangan versi Luther (1994), yang terdiri dari 6 (enam) tahapan, yaitu; concept, design, material collecting, assembly, testing dan distribution. 


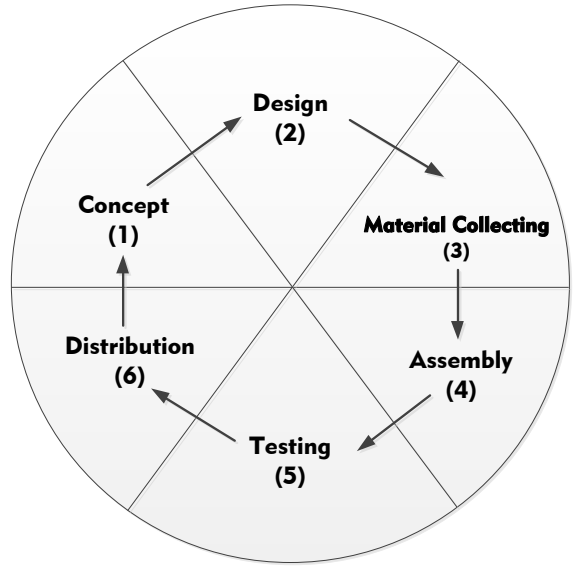

Gambar 6 : Metodologi Pengembangan Sistem Sistem Multimedia

Tahap concept (konsep) merupakan tahap penentuan tujuan, termasuk identifikasi audiens, macam aplikasi (presentasi, interaktif dan lain-lain), tujuan aplikasi (informasi, hiburan, pelatihan dan lain-lain) dan spesifikasi umum. Dasar aturan untuk perancangan juga ditentukan pada tahap ini, seperti ukuran aplikasi, target dan lain-lain.

Tahap design (perancangan) adalah membuat spesifikasi secara rinci mengenai arsitektur proyek, gaya dan kebutuhan material untuk proyek. Spesifikasi dibuat cukup rinci sehingga pada tahap berikutnya, yaitu material collecting dan assembly tidak diperlukan lagi keputusan baru, tetapi menggunakan apa yang sudah ditentukan pada tahap perencanaan. sudah ditentukan pada tahap perencanaan. Perancangan multimedia dapat dibagi menjadi 3 macam (Ariesto Hadi sutopo, 2003): 1). Design berbasis multimedia, Metode design ini dikembangkan dari metode perancangan pembuatan film dengan menggunakan storyboard dan flowchart view. Storyboard merupakan visual test yang pertama-tama dari gagasan dimana secara keseluruhan dapat dilihat apa yang akan disajikan. Bagi designer multimedia, storyboard merupakan pedoman dari aliran pekerjaan yang harus dilakukan. Storyboard merupakan deskripsi tiap scene, dengan mencantumkan semua objek multimedia dan Link ke scene yang lain. Sedangkan Flowchart View disebut juga diagram tampilan adalah diagram yang memberikan gambaran alir dari satu scene (tampilan) ke scene lainnya. 2). Design struktur navigasi Metode ini memberikan gambaran Link dari halaman satu ke halaman yang lainnya. Struktur navigasi digunakan pada multimedia non-linier dan diadaptasi dari design web. yang banyak. (Sutopo, 2003) . 3). Design berorientasi objek Metode desain berorientasi pada objek (object-oriented design) adalah metode Metode desain berorientasi pada objek (object-oriented design) adalah metode berorientasi objek juga digunakan pada banyak sistem yang terdiri dari objek, seperti CAD/CAM, sistem informasi geografis, dan lain-lain. (Sutopo, 2003). Perancangan dapat menggunakan gabungan dari metode tersebut sesuai dengan kebutuhan untuk mendapatkan gambaran struktur sistem secara keseluruhan (Sutopo, 2003).

Tahap material collecting (pengumpulan bahan) dapat dikerjakan paralel dengan tahap assembly. Pada tahap ini dilakukan pengumpulan bahan seperti clipart, image, animasi, audio dan lain-lain yang diperlukan untuk tahap selanjutnya. Bahan yang diperlukan dalam multimedia dapat diperoleh dari sumber-sumber seperti library, bahan yang sudah ada pada pihak lain atau pembuatan khusus yang dilakukan oleh pihak lain.

Tahap assembly (pembuatan) merupakan tahap dimana seluruh objek multimedia dibuat. Pembuatan aplikasi berdasarkan storyboard, flowchart view, struktur navigasi atau diagram objek yang berasal dari tahap design.

Tahap testing (pengujian) dilakukan setelah selesai tahap pembuatan dan seluruh data telah dimasukkan. Suatu hal yang tidak kalah penting yaitu aplikasi harus dapat berjalan dengan baik dilingkungan pengguna. Pengguna merasakan manfaat serta kemudahan dari aplikasi tersebut dan dapat menggunakannya sendiri terutama untuk aplikasi interaktif. 
Tahap distribution (distribusi) merupakan tahap dimana dilakukan evaluasi terhadap suatu produk multimedia. Dengan dilakukannya evaluasi, akan dapat dikembangkan sistem yang lebih baik dikemudian hari.

Berdasarkan 6 (enam) tahapan pengembangan sistem multimedia versi Luther (1994) sebagaimana tersebut di atas, maka pembangunan TV Dakwah berbasis streaming technology ini dapat penulis gambarkan secara detail dalam bagan berikut ini:

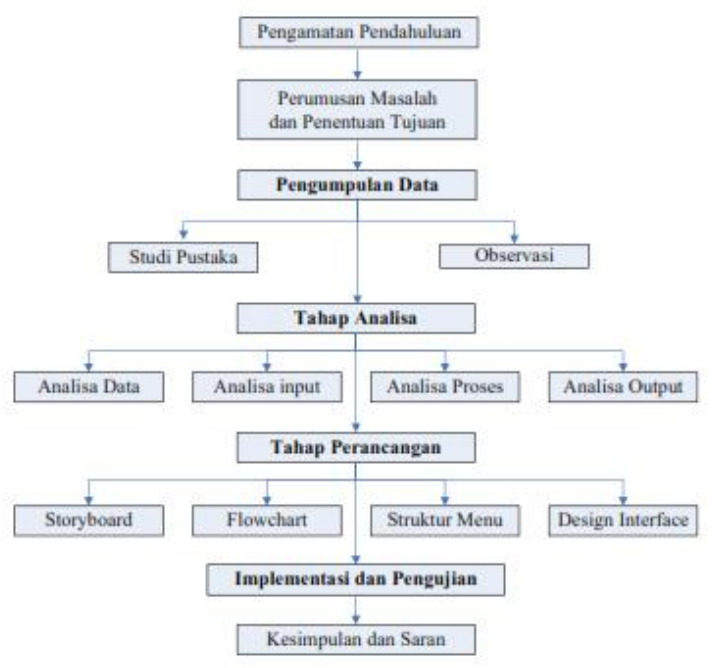

Gambar 7 : Bagan Metodologi Pemnbangunan

TV Dakwah berbasis streaming technology

Adapun spesifikasi perangkat keras (hardware) dan perangkat lunak (software) yang diperlukan dalam mengimplementasikan TV Dakwah berbasis Streaming Technology ini adalah:

1. Perangkat Keras (Hardware)

1.1 Komputer Server

Processor Intel i3, Memory 2 GB, Hard Disk 500 GB, monitor 15", Keyboard dan Mouse standar, bandwith minimal $300 \mathrm{kbps}$.

1.2 Komputer Client

Processor Intel Core, Memory 1 GB, Hard Disk 250 GB, monitor 15", Keyboard dan Mouse standar, bandwith minimal $300 \mathrm{kbps}$.

2. Perangkat Lunak (Software)

2.1 Komputer Server
Windows 7 (Operating System), Windows 7 Media Server + Windows Media Encoder (Live Streaming Server), Windows Media Player (Media Streaming), Mozilla Firefox (Web Browser), PHP (Programming), MySQL (Database), Adobe Dreamweaver (Web Editing), Adobe Photoshop (Layout Editing), TopStyle (CSS optimation), Notepad++ (HTML Editor).

2.2 Komputer Client

Windows 7 OS, Windows Media Server + Windows Media Encoder (Live Streaming Server), Windows Media Player (Media Streaming), Mozilla Firefox (Web Browser)

\section{E. Analisa dan Perancangan}

Analisa sistem yang akan dibangunkan meliputi 4 (empat) kriteria:

Pertama, Analisa Data; Data atau informasi yang dibutuhkan pada TV Dakwah ini sebagai berikut: 1) Data yang berhubungan dengan multimedia yang berfungsi sebagai media informasi utama pada proses TV Dakwah yang menggunakan video streaming dan audio broadcasting berbasisi web. 2) Data teks, teks akan ditampilkan dengan tujuan untuk menampilkan informasi. 3) Data audio atau suara yaitu suara yang akan digunakan pada Video yang ditampilkan pada video On Demand. 4) Data video adalah video yang ditampilkan baik live maupun On Demand.

Kedua, Analisa Input; Alat masukan atau input pada TV Dakwah ini yaitu dengan menggunakan keyboard dan mouse. Pengguna hanya menggunakan keyboard dan mouse untuk melakukan interaksi pada sistem.

Ketiga, Analisa Proses; Proses aplikasi yang akan di buat, dalam analisa proses dijelaskan proses live streaming dan On Demand. Video live streaming adalah video yang menampilkan kegiatan yang sedang berlangsung pada hari itu dan menampilkankannya secara langsung. On Demand adalah tampilan video yang 
sudah direkam terlebih dahulu kemudian di masukkan ke dalam hardisk server TV Dakwah dan bisa dilihat berulang-ulang.

Keempat, Analisa Output; Output yang diharapkan dari Implementasi TV Dakwah dengan menggunakan Teknologi Video Streaming dan Audio Broadcasting Berbasis Web adalah berupa video live streaming dan video $O n$ Demand yang berisi materi dakwah dalam berbagai bentuk program siaran.

Setelah proses analisis selesai, tahap selanjutnya adalah perancangan sistem yang meliputi 4 (empat) tahapan:

Pertama, Storyboard, untuk halaman awal yang merupakan awal penggunaan sistem oleh pengguna, kemudian storyboard untuk scene berikut yaitu halaman tempat menu seluruh topik yang akan ditampilkan. Storyboard yang akan dikembangkan untuk setiap menu yaitu:

1. Scene 1 - merupakan menu awal dan juga menu utama yang terdiri dari 10 (sepuluh) submenu yaitu about us, contact us, Help, download, Google Search, statistik, Login, polling, kalender dan content video $O n$ Demand.

2. Scene 1.1 - menu About us merupakan menu yang membahas mengenai sejarah dan tentang web.

3. Scene 1.2 - menu countact us merupakan menu yang membahas identitas programer dan alamat.

4. Scene 1.3 - menu Help merupakan menu yang membahas petunjuk penggunaan.

5. Scene 1.4 - menu download merupakan menu yang membahas menyediakan aplikasi pendukund broadcasting.

6. Scene 1.5 - google search merupakan menu untuk pencarian lewat google.co.id.

7. Scene 1.6 -statistik merupakan menu yang membahas berapa kali web ini diakses user, berapa user yang akses, pengaksesan perhari, dan berapa user yang aktif hari ini.

8. Scene 1.7 - Login merupakan menu untuk memasuki tampilan user/Admin. User wajib memasukan username dan password, kalau belum mendaftar user tidak dapat memasuki ke tampilan selanjutnya.

9. Scene 1.8 - polling merupakan menu untuk penilaian user.

10. Scene 1.9 - kalender merupakan menu untuk melihat tanggal, bulan, dan tahun.

11. Scene 1.10 - video On Demand merupakan menu untuk melihat video yang telah disimpan didalam hardisk server.

Kedua, Flowchart, menjelaskan proses dan prosedur yang terjadi pada sistem dengan simbol-simbol tertentu sehingga dapat menggambarkan alur yang terjadi. Dengan penggunaan flowchart memungkinkan penggambaran keseluruhan dari pengambilan data awal hingga dihasilkan keluaran yang diinginkan.

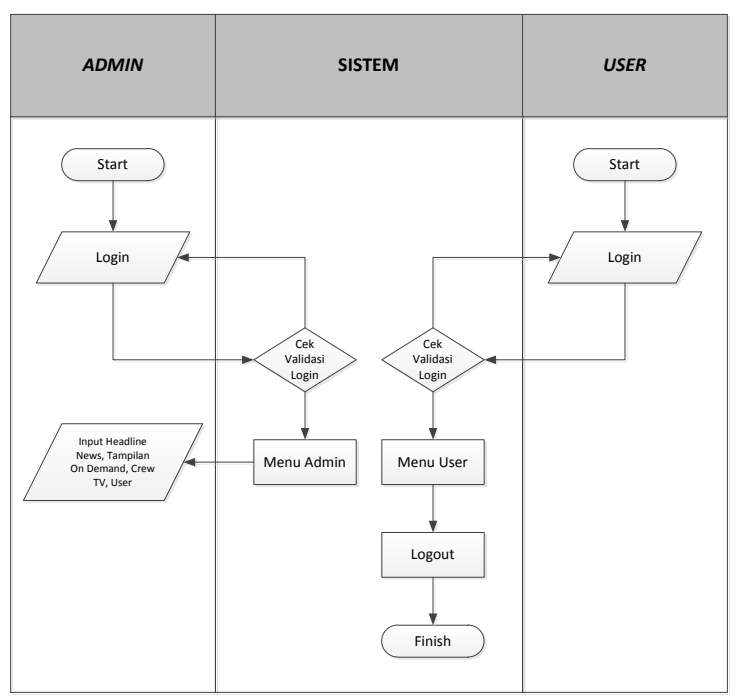

Gambar 8 : Flowchart Sistem

Ketiga, Struktur Menu; beberapa rancangan struktur menu aplikasi yang dirancang untuk Aplikasi Video Live Streaming dan Audio Broadcasting untuk TV Dakwah, adalah: 


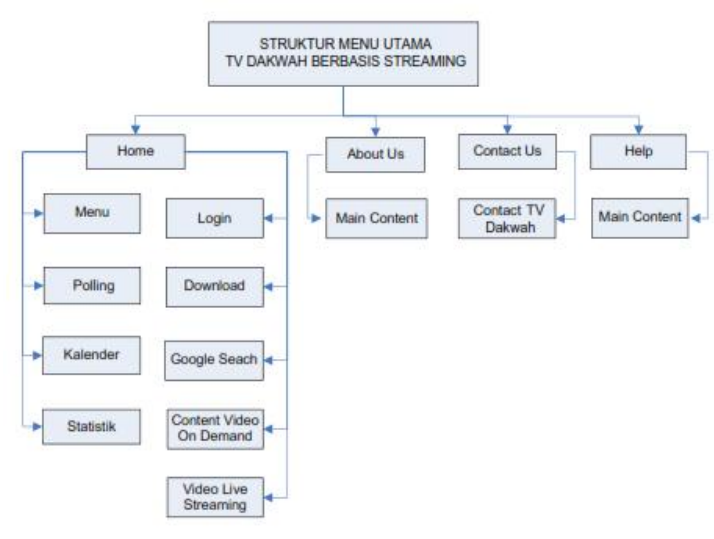

Gambar 9 : Struktur Menu Halaman Utama

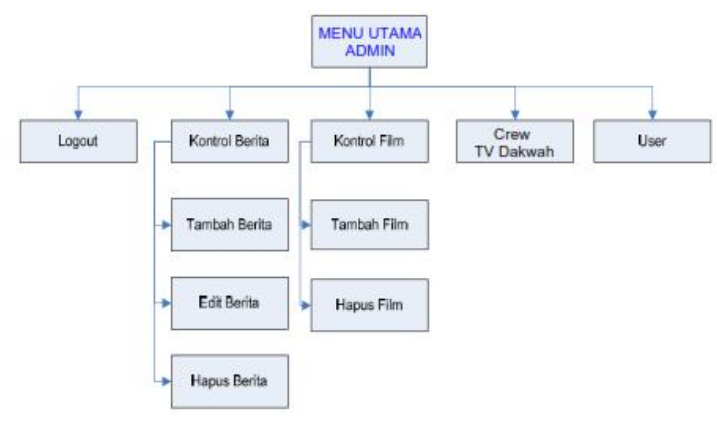

Gambar 10 : Struktur Menu Halaman Admin

Keempat, Design Interface; beberapa rancangan antarmuka, yang akan diaplikasikan dalam Aplikasi Video Live Streaming dan Audio Broadcasting untuk TV Dakwah, adalah: a. Antarmuka Halaman Utama

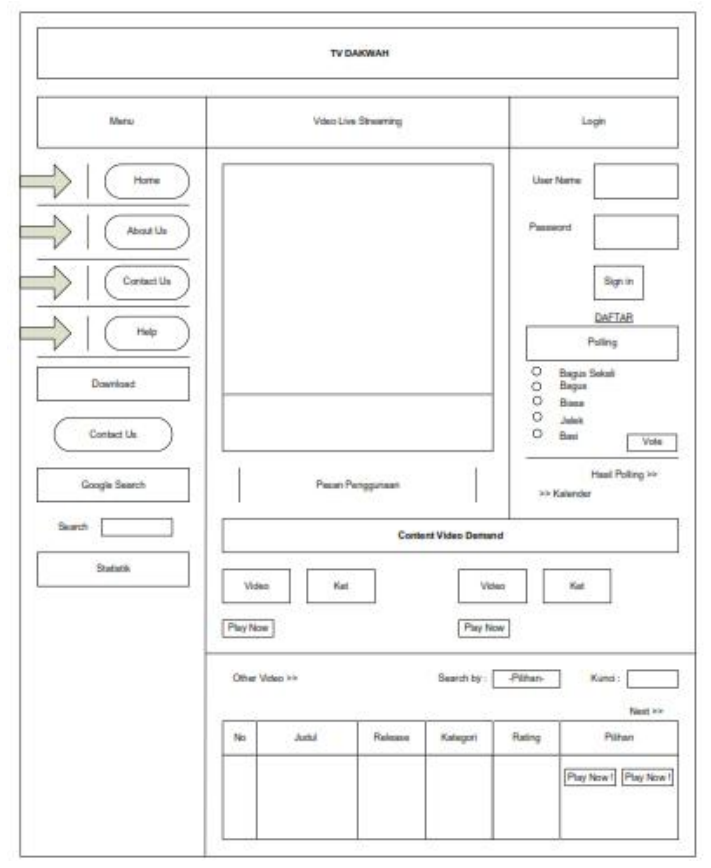

Gambar 11 : Antarmuka Halaman Utama

Ket: 1. Header Web TV Dakwah.

2. Logo TV Dakwah

3. Menu yang disediakan Web TV Dakwah yaitu :

3.1 Home memuat aplikasi inti

3.2 About Us memuat sejarah dan tentang web.

3.3 Contact Us memuat tentang identitas programmer.

3.4 Help memuat petunjuk penggunaan.

4. Fasilitas Download menyediakan aplikasi pendukung broadcasting.

5. Google Search. Link ke pencarian lewat google.co.id

6. Statistik menampilkan keterangan berapa kali web ini di akses user, berapa user yang akses, pengaksesan perhari, dan berapa user yang akti hari ini.

7. Fasilitas Video live Streaming adalah aplikasi video langsung tanpa perekaman terlebih dahulu.

7.1 Play Video Live Streaming.

7.2 Pesan Penggunaan bergerak dari kanan ke kiri. 
8. Login. Fasilitas Login digunakan untuk memasuki Tampilan User/Admin. User wajib memasukan Username dan Password. Kalau belum mendaftar user tidak dapat memasuki Tampilan selanjutnya.

8.1 Masukan Username dan

Password kemudian klik SignIn untuk masuk tampilan selanjutnya.

8.2 Link Daftar untuk Registrasi User.

9. Fasilitas Polling untuk penilaian user. 9.1. Melihat Hasil Polling.

9.2. Melihat Kalender.

10. Content Video On Demand menampilkan video yang telah direkam dan broadcastkan.

10.1 Video On Demand tentang Film, Kegiatan, Program Acara yang sudah disiapkam. b. Antarmuka Halaman About Us

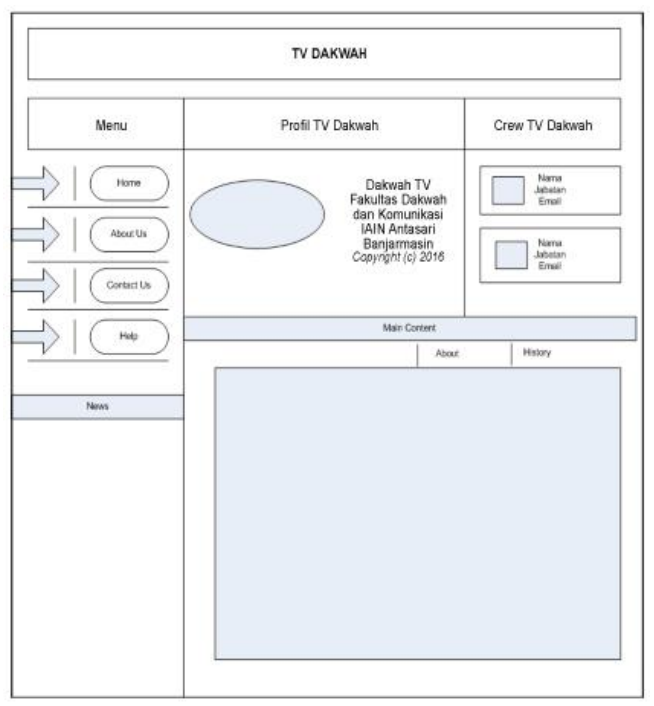

Gambar 12 : Antarmuka Halaman About Us

Ket: 1. Header Web TV Dakwah

2. Logo TV Dakwah

3. Menu yang disediakan Web TV Dakwah yaitu :

3.1 Home memuat aplikasi inti

3.2 About Us memuat sejarah dan tentang web.

3.3 Contact Us memuat tentang identitas programmer.

3.4 Help memuat petunjuk penggunaan.

4. News merupakan fasilitas berita terbaru tentang info terkini

5. Profile TV Dakwah menampilkan identitas TV Dakwah.

5.1 Motto TV Dakwah berjalan dari kiri ke kanan.

5.2 Logo TV Dakwah.

5.3 Identitas TV Dakwah.

5.4 Play Profile TV Dakwah.

5.5 Keterangan penggunaan aplikasi.

6. Crew TV Dakwah mengenai anggota TV Dakwah.

6.1 Foto anggota.

6.2 Identitas anggota.

7. Main Content.

7.1 Sejarah

c. Antarmuka Halaman Contact Us

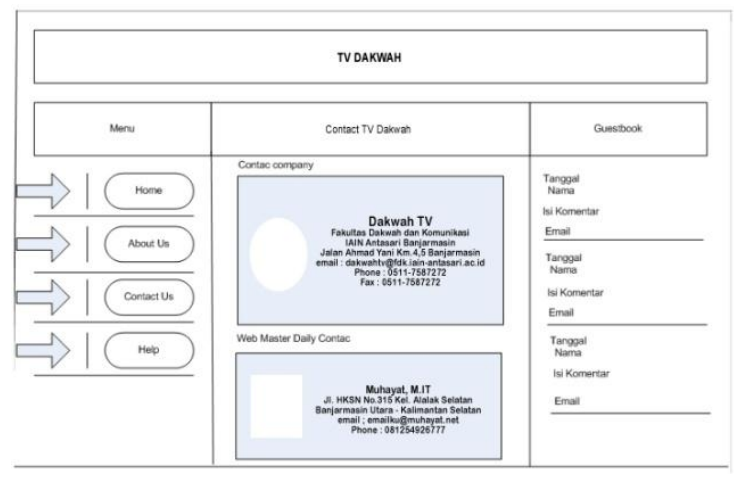

Gambar 13 : Antarmuka Halaman Contact Us

Ket: 1. Header Web TV Dakwah

2. Logo TV Dakwah 
3. Menu yang disediakan Web TV Dakwah yaitu :

3.1 Home memuat aplikasi inti

3.2 About Us memuat sejarah dan tentang web.

3.3 Contact Us memuat tentang identitas programmer.

3.4 Help memuat petunjuk penggunaan.

4. Contact TV Dakwah

4.1 Logo TV Dakwah

4.2 Alamat TV Dakwah

4.3 Foto Web Master

4.4 Alamat Web Master

5. Guestbook berisi tanggal, nama pengirim, isi komentar, dan alamat email pengirim. Tulisan berjalan dari bawah ke atas.

d. Antarmuka Halaman Help

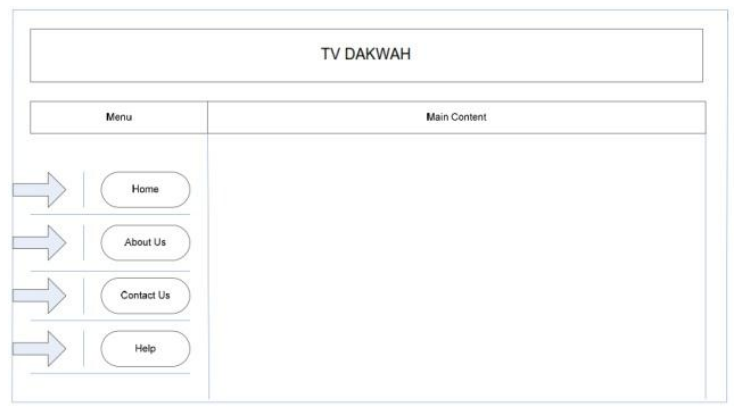

Gambar 14 : Antarmuka Halaman Help

Ket: 1. Header Web TV Dakwah

2. Logo TV Dakwah

3. Menu yang disediakan Web TV Dakwah yaitu :

3.1 Home memuat aplikasi inti

3.2 About Us memuat sejarah dan tentang web.

3.3 Contact Us memuat tentang identitas programmer.

3.4 Help memuat petunjuk penggunaan.

4. Main Content berisi tentang pertolongan menjalankan aplikasi, peraturan-peraturan dan spesifikasi hardware.

e. Antarmuka Halaman Admin

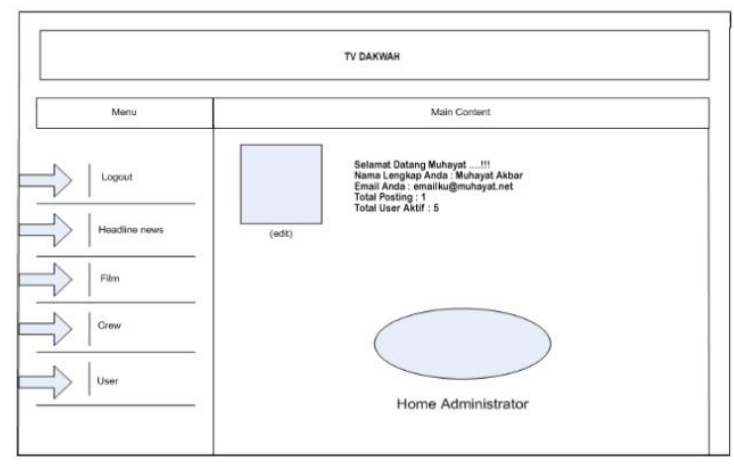

Gambar 15 : Antarmuka Halaman Admin

Ket: 1. Header Web TV Dakwah

2. Logo TV Dakwah

3. Menu yang terdapat pada Admin:

3.1 Logout untuk menutup halaman Admin dan menghapus session.

3.2 Berita merupakan fasilitas informasi tentang apapun dalam bentuk teks.

3.3 Film merupakan controling database film untuk Video On Demand.

3.4 Crew TV merupakan kontroler untuk menginputkan anggota TV Dakwah.

3.5 User merupakan untuk melihat User yang aktif

4. Main Content.

4.1 Foto Administrator, dapat diubah sesuai dengan keinginan.

4.2 Identitas Admin, nama, email, total posting dan total aktif user.

4.3 Logo TV Dakwah.

f. Antarmuka Headline News

Albiwar Jumal Ilmu dan Teknik Dakwah Vol. 04 No. 07 Januari-Juni 2016 


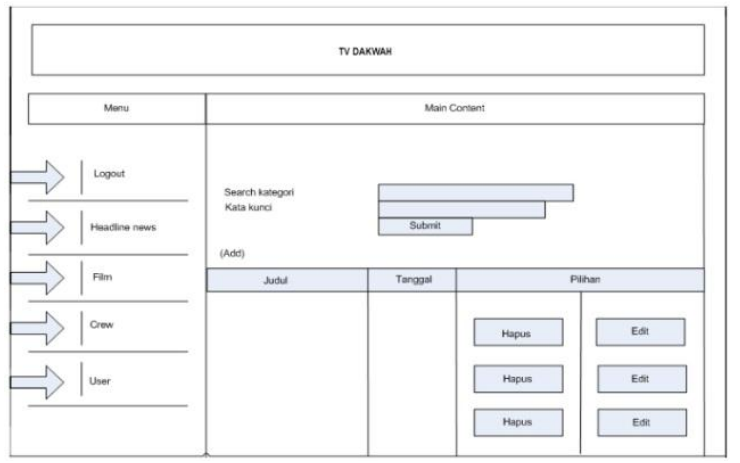

Gambar 16 : Antarmuka Headline News

Ket: 1. Header Web TV Dakwah

2. Logo TV Dakwah

3. Menu yang terdapat pada $A d m i n$ :

3.1 Logout untuk menutup halaman Admin dan menghapus session.

3.2 Berita merupakan fasilitas informasi tentang apapun dalam bentuk teks.

3.3 Film merupakan kontroling database film untuk Video $\mathrm{On}$ Demand.

3.4 Crew TV merupakan kontroler untuk menginputkan anggota TV Dakwah.

3.5 User merupakan untuk melihat User yang aktif.

4. Main Content.

4.1 Judul berita dapat diedit dan diganti oleh Admin.

4.2 Tanggal berita.

4.3 Pilihan terdapat 2 conten, hapus dan edit.

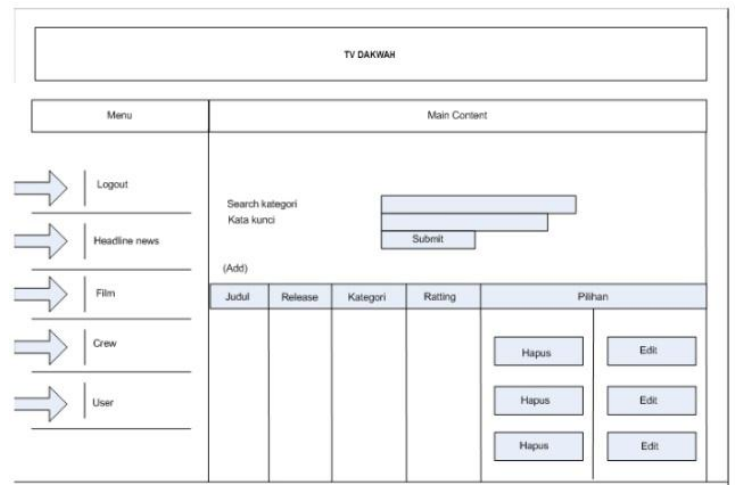

Gambar 16 : Antarmuka Film

Ket: 1. Header Web TV Dakwah

2. Logo TV Dakwah

3. Menu yang terdapat pada Admin:

3.1 Logout untuk menutup halaman Admin dan menghapus session.

3.2 Berita merupakan fasilitas informasi tentang apapun dalam bentuk teks.

3.3 Film merupakan kontroling database film untuk Video On Demand.

3.4 Crew TV merupakan kontroler untuk menginputkan anggota TV Dakwah.

3.5 User merupakan untuk melihat User yang aktif.

4. Main Content.

4.1 Judul Film dapat diganti dan diedit oleh Admin.

4.2 Release merupakan kapan film ini dimasukan

4.3 Kategori merupakan jenis film apa yang di tampilkan

4.4 Ratting merupakan melihat banyak nya user yang mengunjungi film tersebut.

4.5 Pilihan terdapat 2 conten, hapus dan edit.

g. Antarmuka Film

h. Antarmuka Crew TV 


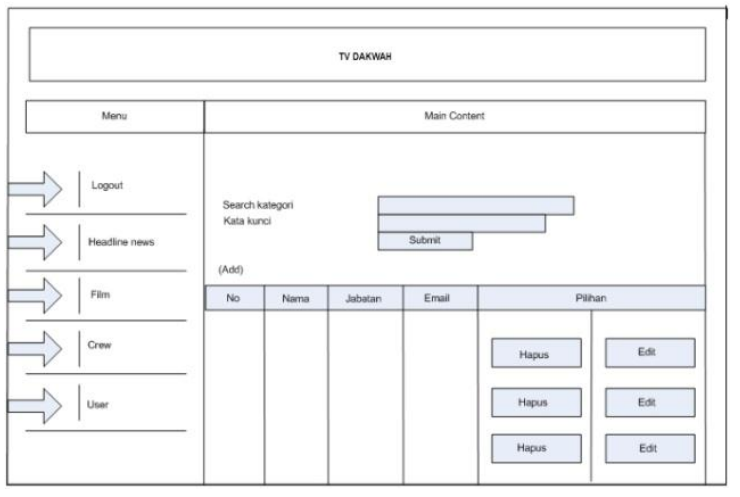

Gambar 17 : Antarmuka Crew TV

Ket: 1. Header Web TV Dakwah

2. Logo TV Dakwah

3. Menu yang terdapat pada Admin:

3.1 Logout untuk menutup halaman Admin dan menghapus session.

3.2 Berita merupakan fasilitas informasi tentang apapun dalam bentuk teks.

3.3 Film merupakan kontroling database film untuk Video $O n$ Demand.

3.4 Crew TV merupakan kontroler untuk menginputkan anggota TV Dakwah.

3.5 User merupakan untuk melihat User yang aktif.

4. Main Content.

\subsection{Nomor}

4.2 Nama anggota TV Dakwah.

4.3 Jabatan anggota TV Dakwah.

4.4 Email anggota TV Dakwah.

4.5 Pilihan terdapat 2 conten, hapus dan edit. i. Antarmuka User

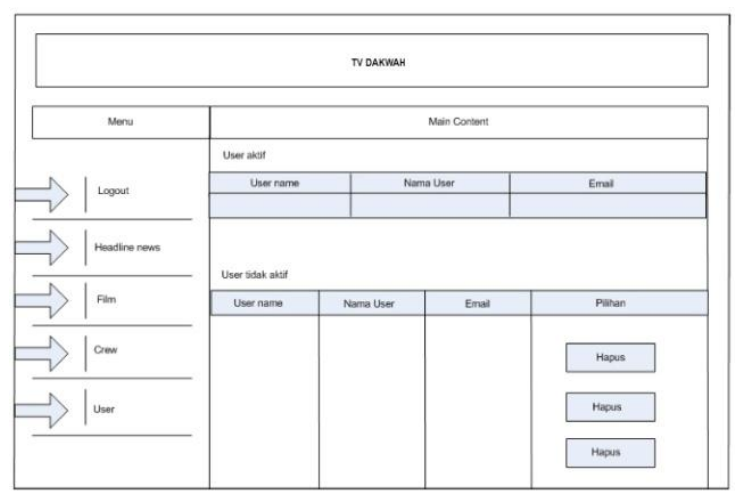

Gambar 18 : Antarmuka User

Ket: 1. Header Web TV Dakwah

2. Logo TV Dakwah

3. Menu yang terdapat pada Admin:

3.1 Logout untuk menutup halaman Admin dan menghapus session.

3.2 Berita merupakan fasilitas informasi tentang apapun dalam bentuk teks.

3.3 Film merupakan kontroling database film untuk Video $O n$ Demand.

3.4 Crew TV merupakan kontroler untuk menginputkan anggota TV Dakwah.

3.5 User merupakan untuk melihat User yang aktif.

4. Main Content.

4.1 User aktif

4.1.1 Usemame merupakan user untuk Login.

4.1.2 Nama User merupakan nama lengkap pengguna.

4.1.3 Email pengguna.

4.2 User tidak aktif.

4.2.1 Username merupakan user untuk Login.

4.2.2 Nama User merupakan nama lengkap pengguna.

4.2.3 Email pengguna.

4.2.4 Pilihan terdapat 2 conten, hapus dan edit. 
j. Antarmuka Halaman Client

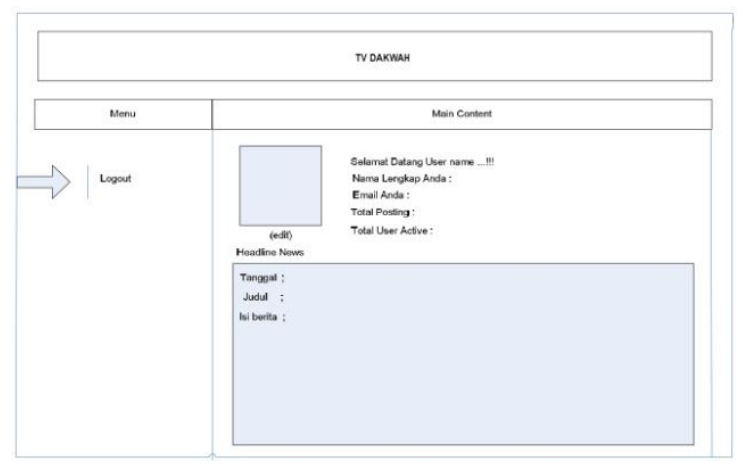

Gambar 19 : Antarmuka Halaman Client

Ket: 1. Header Web TV Dakwah

2. Logo TV Dakwah

3. Menu yang terdapat pada User:

3.1 Logout untuk menutup halaman Admin dan menghapus session.

4. Main Content

4.1 Foto User, dapat diubah sesuai dengan keinginan.

4.2 Identitas User, nama, email, total posting dan total aktif user.

4.3 Headline News menampilkan berita terkini.

\section{F. Penutup}

Berdasarkan hasil kajian yang telah dilakukan sejak dari tahap perumusan masalah, penentuan tujuan, analisis dan perancangan TV Dakwah berbasis Streaming Technology, maka penulis dapat mengambil suatu kesimpulan:

1. Membangun TV Dakwah menjadi suatu keharusan bagi para pegiat dakwah dalam rangka menyambut tantangan zaman yang semakin maju.

2. TV Dakwah dapat diwujudkan dengan lebih cepat jika menggunakan Teknologi Streaming yang memungkinkan dapat melakukan siaran secara Real-Time maupun On Demand dengan biaya yang murah jika dibandingkan membangun TV Dakwah dengan teknologi konvensional.

3. Hasil analisis dan perancangan menghasilkan bahwa TV Dakwah yang akan dibangunkan memiliki 13 modul yang akan diimplementasikan, yakni: Modul layar utama (menampilkan video live streaming), Modul About Us (Memuat sejarah dan tentang web TV dakwah), Modul Contact Us (Memuat Identitas TV dan Programmer), Modul Help (Petunjuk Penggunaan), Modul Daftar (Daftar User Baru), Modul Login (Login Admin / User), Modul Logout (Keluar dari halaman Admin / User), Modul Headline News (Menampilkan Berita), Modul Film (Menampilkan Juduljudul film/video), Modul Download (Aplikasi pendukung TV Streaming), Modul Crew (Controller anggota Crew TV Dakwah), Modul User (Menampilkan anggota terdaftar), Modul Play Now (memutar film/video yang tersediaa di content video On Demand).

Agar sistem ini dapat terwujud dengan baik, maka penulis memberikan beberapa saran sebagai berikut:

1. Diharapkan sistem ini dapat berlanjut hingga tahap implementasi dan pengujian.

2. Agar aplikasi TV Dakwah ini dapat berjalan dengan maksimal, diperlukan spesifikasi komputer server yang tinggi, minimal dengan processor Core i5, memory 16 GB, hardisk 1 Terabyte.

3. Aplikasi ini berbentuk $W e b$ yang terkoneksi dengan jaringan internat, sehingga memerlukan bandwith koneksi internet yang cukup (minimal 1 Mbps) agar proses streaming data (video) dari komputer server ke komputer client dapat berjalan dengan lancar. 


\section{DAFTAR PUSTAKA}

Al-Khudri. Abu Sa'id, Syahwat Televisi: Menggugat Tayangan Vulgar, Bandung: Mujahid Press, 2005. Amin, M. S., Ilmu Dakwah, Jakarta, Amzah, 2009.

Azikin, Askari dan Purwanto Yudha, ST., Video / TV Streaming Dengan Video Lan Project, 2005.

Departemen Agama Republik Indonesia, Al-Qur'an dan Terjemahnya, Bandung, CV Penerbit JArt, 2004.

Fatmawati, Paradigma Baru Mengemas Dakwah Melalui Media Televisi Di Era Globalisasi, Jurnal Komunika Volume 3, Nomor 2, Juli-Desember 2009. Hal 184-194, 2009.

Ilaihi. Wahyu, Komunikasi Dakwah, Bandung, PT. Remaja Rosdakarya, 2010.

Muda. I. D., Jurnalistik Televisi, Bandung, PT. Remaja Rosda Karya, 2009.

Prabhat K. Andleigh dan Kiran Thakrar, Multimedia System Design, Prentice Hall, New Jersey, 1996.

Rahmi. A., Dakwah Melalui Media Penyiaran, Jurnal Ilmu Dakwah, Volume 32, Nomor 2, JuliDesember 2012. Hlm 209- 222, 2012.

Saputra. W., Pengantar Ilmu Dakwah, Jakarta, PT. Graha Grafindo Husada, 2011. 